\title{
PENDIDIKAN ISLAM DALAM ERA REVOLUSI INDUSTRI 4.0
}

\author{
Abdul Hakim bin Abdullah \\ Universiti Sultan Zainal Abidin, Terengganu, Malaysia. \\ Emel: hakimabd@unisza.edu.my
}

\begin{abstract}
Abstrak: Pelbagai penemuan dan ciptaan baharu telah dihasilkan oleh manusia yang telah memberi kesan yang besar terhadap kualiti kehidupan manusia di seluruh dunia. Di antara perkembangan yang ketara ialah berlakunya perluasan penggunaan teknologi automasi, robotik dan Internet of Things (IoT) yang mengembangkan industri-industri dalam bentuk baharu seperti industri atas talian, industri data raya (big data), industri robot, industri keselamatan rangkaian dan industri realiti maya (virtual reality). Ketibaan siri revolusi industri terbaharu mula dirasai oleh masyarakat dunia dan sememangnya siri yang kelima pasti akan muncul tidak lama lagi dengan fenomena-fenomena baharu yang akan memberi kesan yang besar terhadap kehidupan manusia dari segenap aspek. Sejak dahulu lagi, beberapa orang pemikir Barat sendiri cuba mengingatkan masyarakat terhadap implikasi kedatangan era revolusi versi baharu. Pendidikan Islam yang dimaksudkan di sini ialah proses pendidikan yang mengutamakan konsep tarbiyyah, ta'lim dan ta'dib. Dalam apa jua mata pelajaran yang dipelajari, ketiga-tiga konsep tadi haruslah ditekankan oleh para pendidik. Satu lagi konsep yang menjadi penekanan pendidikan Islam ialah pendidikan bersepadu (integrated education) yang telah lama dibincangkan secara terperinci oleh para sarjana.
\end{abstract}

Kata Kunci: pendidikan Islam, revolusi industri 4.0 
Kejayaan manusia dalam penerokaan ilmu pengetahuan dalam pelbagai bidang pada hari ini memacu kepada kemajuan dalam sains dan teknologi. Pelbagai penemuan dan ciptaan baharu telah dihasilkan oleh manusia yang telah memberi kesan yang besar terhadap kualiti kehidupan manusia di seluruh dunia. Di antara perkembangan yang ketara ialah berlakunya perluasan penggunaan teknologi automasi, robotik dan Internet of Things (IoT) yang mengembangkan industri-industri dalam bentuk baharu seperti industri atas talian, industri data raya (big data), industri robot, industri keselamatan rangkaian dan industri realiti maya (virtual reality).

Perkembangan ini menyebabkan para sarjana menamakan zaman ini sebagai era revolusi industri 4.0 atau dengan kata lain, era revolusi gelombang ke-4. Fenomena baharu ini telah dianggap sebagai kelaziman dalam masyarakat moden malah banyak negara berlumba-lumba untuk menjuarai teknologi dalam era revolusi industri 4.0 ini. Mana-mana negara yang mengabaikan kemajuan teknologi akan menjadi sebuah negara yang lemah, mudah dikuasai oleh anasir asing dan tidak mampu mencorakkan pembangunan negara mengikut acuan sendiri. Tidak dapat dinafikan bahawa kemajuan teknologi mesti dikuasai bagi memastikan negara tidak ketinggalan dalam segenap aspek sama ada politik, ekonomi mahupun sosial.

Secara asasnya, perkembangan manusia dalam penerokaan ilmu pengetahuan dan penemuan serta ciptaan baharu sepatutnya akan mempertingkatkan lagi peradaban manusia. Dengan kata lain, semakin tinggi ilmu pengetahuan manusia, semakin tinggilah peradaban manusia. Ini selaras dengan pengertian tamadun iaitu, keadaan masyarakat manusia yang berdasarkan taraf kemajuan kebendaan serta perkembangan pemikiran (sosial, budaya, politik dan lainlain) yang tinggi peradabannya (Kamus Dewan, 2007). Ibnu Khaldun (1990) mendefinisikan tamadun sebagai pencapaian manusia yang melebihi keperluan asasi kehidupan sehingga dapat membuka jalan ke arah pemikiran dan penghasilan daya cipta yang lebih halus dan mempunyai nilai-nilai seni. Manakala Syed Naquib al-Attas (1977) pula mendefinisikan tamadun sebagai keadaan kehidupan insan yang bermasyarakat yang telah mencapai taraf tatasusila dan kebudayaan yang luhur bagi seluruh masyarakat.

\section{Beberapa Konflik dalam Masyarakat} Era Revolusi Industri 4.0

Ketibaan siri revolusi industri terbaharu mula dirasai oleh masyarakat dunia dan sememangnya siri yang kelima pasti akan muncul tidak lama lagi dengan fenomena- 
fenomena baharu yang akan memberi kesan yang besar terhadap kehidupan manusia dari segenap aspek. Sejak dahulu lagi, beberapa orang pemikir Barat sendiri cuba mengingatkan masyarakat terhadap implikasi kedatangan era revolusi versi baharu. Di antara mereka ialah Alvin Toffler (1970) dalam karyanya "Future Shock" menyatakan bahawa akan muncul super industrial society. Dengan ledakan maklumat yang beliau anggap sebagai "too much change in too short a period of time" akan berlaku stress, kekeliruan dan kurangnya interaksi bersemuka sesama individu masyarakat. Manakala Neil Postman pula menegaskan bahawa teknologi baharu boleh mendatangkan banyak peluang berbanding kemusnahan, dan teknologi baharu juga boleh membawa banyak kemusnahan berbanding peluang yang diciptanya. Beliau berkata dalam ucapannya kepada Persatuan Informatik Jerman pada tahun 1990: "We don't know how to filter it, we don't know how to reduce it, we don't know how to use it. We suffer from a kind of cultural AIDS" (lihat Joy A. Palmer, 2016).

Di negara kita, kemajuan teknologi online telah mengatasi teknologi on-air. Kepesatan teknologi pada hari ini turut mengundang beberapa kesan negatif yang dialami seperti gejala sosial; penipuan atas talian; penularan industri seks; penyebaran berita palsu; dominasi Barat dalam mengendalikan sistem perbankan, sistem operasi dan perisian komputer, industri media, komunikasi dan hiburan; perpecahan masyarakat; kepudaran kemanusiaan; stress dan kekeliruan; ketagihan internet; ajaran sesat dan ekstremisme; ketiadaan "zaman kanak-kanak" dan lain-lain lagi.

Para cendekiawan negara sentiasa mengingatkan semua lapisan masyarakat agar bersedia dan berupaya menghadapi cabaran-cabaran yang timbul pada era revolusi industri 4.0. Kerajaan menerusi Kementerian Pendidikan turut mengambil inisiatif bagi menghadapi era ini dan memperkenalkan Pendidikan 4.0 sebagai satu inisiatif besar bagi memastikan negara kita berupaya menyediakan modal insan yang berkualiti dan cekap serta berupaya menjadi penggerak kepada pembinaan kemajuan dan tamadun negara. Pembangunan modal insan sangat penting bagi menjamin kesinambungan tamadun negara. Sekiranya berlaku keruntuhan atau kemerosotan dalam sesebuah negara, ia bukan disebabkan oleh ilmu atau teknologi yang ada, akan tetapi adalah disebabkan oleh kepincangan-kepincangan yang terdapat pada manusia yang dibangunkan tersebut. Firman Allah s.w.t.:

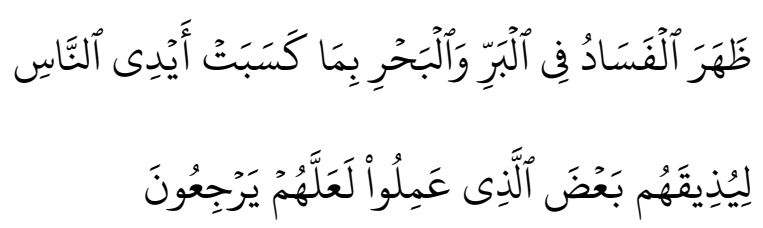


Terjemahan: "Telah timbul berbagai kerosakan dan bala bencana di darat dan di laut dengan sebab apa yang telah dilakukan oleh tangan manusia; (timbulnya yang demikian) kerana Allah hendak merasakan mereka sebahagian dari balasan perbuatanperbuatan buruk yang mereka telah lakukan, supaya mereka kembali (insaf dan bertaubat)" (al-Rum: 41).

\section{Strategi Pemerkasaan Ummah}

\section{Menerusi Pendidikan Islam}

Pendidikan Islam yang dimaksudkan di sini ialah proses pendidikan yang mengutamakan konsep tarbiyyah, ta'lim dan ta'dib. Dalam apa jua mata pelajaran yang dipelajari, ketiga-tiga konsep tadi haruslah ditekankan oleh para pendidik. Satu lagi konsep yang menjadi penekanan pendidikan Islam ialah pendidikan bersepadu (integrated education) yang telah lama dibincangkan secara terperinci oleh para sarjana. Beberapa orang tokoh pendidik Malaysia telah mengemukakan definisi pendidikan bersepadu di antaranya ialah:

1. "Pendidikan Sepadu adalah pendidikan yang berdasarkan falsafah kesepaduan di antara iman dan ilmu, jasad dan roh, dunia dan din, fikiran dan hati, akal dan wahyu. Menerusi falsafah kesepaduan ini maka dapatlah dididik manusia supaya tunduk kepada tuntutan akidah
Islam, syariah Islam dan akhlak Islam" (Mohd Kamal Hassan, 1984).

2. "Pendidikan Sepadu merupakan seluruh proses pendidikan dan perkembangan ilmu yang tidak terpisah dari tauhid. Sama ada rohani, jasmani dan akli, coraknya adalah bersepadu. Lantaran itu, segala ilmu bersifat qudus dan sekaligus penglibatannya merupakan ibadah bagi manusia" (Abdul Halim Muhammad, 1984).

3. Tajul Ariffin Noordin \& Abdul Raof Dalip (1986) merumuskan pendidikan sepadu sebagai "Pendidikan yang berteraskan al-Quran dan alSunnah yang disepadukan dengan disiplin ilmu akal ke arah membina masyarakat ummah yang berteraskan akidah" (lihat juga Tajul Ariffin [2005]).

Daripada definisi-definisi di atas, dapat dirumuskan bahawa pendekatan bersepadu merupakan satu pendekatan yang berasaskan akidah. Ia menekankan pengembangan potensi insan secara bersepadu ke arah melahirkan insan terdidik. Pendekatan bersepadu mementingkan kesepaduan dan keseimbangan di antara:

1. Agama dan dunia;

Ilmu naqli dan ilmu aqli; 
2. Ilmu tradisi dan kontemporari;

3. Ilmu fardu ain dan fardu kifayah;

4. Rohani, jasmani, emosi dan intelek;

5. Kognitif, psikomotor dan afektif;

6. Teori dan praktis; dan

7. Kecemerlangan teknologi dan nilai insani.

\section{Asas-asas Pendekatan Bersepadu}

Asas-asas utama pendekatan bersepadu yang perlu difahami dan dihayati dalam melaksanakan misi pendidikan ialah:

1. Tauhid merupakan tunjang pendidikan. Ia adalah pegangan mengesakan Allah s.w.t. Asas ini menanam ke dalam diri manusia bahawa segala yang mawjud dalam alam semesta ini adalah ciptaan Allah s.w.t. dan semua wajib patuh menyembah dan beribadah kepadaNya. Ia menjadi kekuatan dalaman insan yang memberi motivasi kepadanya untuk mencapai kesejahteraan di dunia dan akhirat dengan mengerjakan apa yang disuruh dan meninggalkan apa yang dilarang oleh Allah s.w.t.

2. Manusia perlu dibina selaras dengan fungsi dan tanggungjawabnya sebagai khalifah dan hambaNya di atas muka bumi ini. Firman Allah s.w.t.:

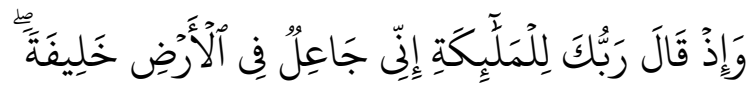

Terjemahan: "Dan (ingatlah) ketika Tuhanmu berfirman kepada Malaikat; "Sesungguhnya Aku hendak menjadikan seorang khalifah di bumi..." (al-Baqarah: 30).

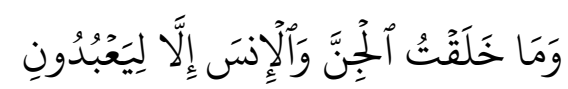

Terjemahan: "Dan (ingatlah) Aku tidak menciptakan jin dan manusia melainkan untuk mereka menyembah dan beribadat kepadaKu" (al-Dhariyat: 56).

Sebagai khalifah dan hambaNya, manusia perlu diberi didikan yang merangkumi aspek-aspek penting tamadun (menurut acuan Islam) iaitu mengenali Allah s.w.t., hakikat insan dan alam semesta. Apabila seseorang melalui proses pendidikan secara berterusan, menyeluruh dan seimbang, maka akan terhasil kesan sebenar pendidikan iaitu memperoleh taqwa dan hikmah. Firman Allah s.w.t:

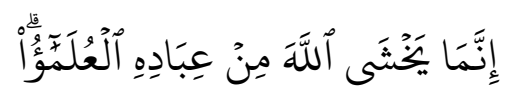

Terjemahan: "Sebenarnya yang menaruh bimbang dan takut (melanggar perintah) Allah dari kalangan hambahambaNya hanyalah orang-orang yang berilmu" (Fatir: 28). 


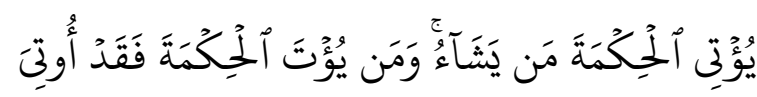

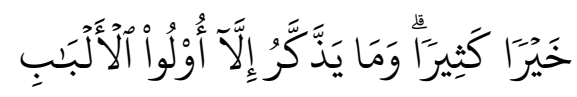

Terjemahan: "Allah memberikan hikmat kebijaksanaan (ilmu yang berguna) kepada sesiapa yang dikehendakiNya (menurut aturan yang ditentukanNya). Dan sesiapa yang diberikan hikmat itu maka sesungguhnya ia telah diberikan kebaikan yang banyak. Dan tiadalah yang dapat mengambil pengajaran (dan peringatan) melainkan orang-orang yang menggunakan akal fikirannya" (al-Baqarah: 269).

Masyarakat terdidik yang mempunyai takwa dan hikmah akan membentuk satu generasi yang digelar oleh al-Quran sebagai ulul albab. Al-Tabari (1987) menjelaskan bahawa golongan ulul albab ialah mereka yang sentiasa memanfaatkan kehebatan akal fikiran untuk memahami hakikat Allah, suruhan dan laranganNya serta sentiasa berfikir tentang tanda-tanda kebesaran Allah s.w.t.. Menurut al-Fakhr al-Razi (t. th.) pula, ulul albab ialah orang-orang yang sentiasa berpandangan jauh dan memikirkan tentang implikasi sesuatu perkara. Selain itu, beliau juga menyifatkan ulul albab sebagai orangorang yang tahu membezakan di antara yang baik dan buruk. Sacid Hawwa (1989) pula menyatakan bahawa ulul albab adalah satu kelompok manusia yang dipuji oleh Allah, mereka adalah golongan pemikir yang sentiasa memanfaatkan akal, melakukan pemerhatian yang baik serta melaksanakan tanggungjawab dengan betul. Ibn Kathir (t. th.) menjelaskan bahawa ulul albab adalah orang-orang yang mempunyai akal fikiran yang sempurna lagi bersih yang dapat memahami sepenuhnya tentang hakikat sesuatu. Mereka juga dapat memahami kejadian langit dan bumi yang penuh dengan hikmah dan menginsafi kebesaran, kekuasaan, pengetahuan, penentuan dan rahmatNya.

Pendekatan bersepadu menekankan kesepaduan dan kesimbangan dalam penguasaan imu-ilmu naqli dan aqli. Khayr ummah hanya dapat direalisasikan menerusi penguasaan secara bersepadu dan seimbang terhadap ilmu naqli dan ilmu aqli. Ramai tokoh ilmuan Islam pada zaman kegemilangan tamadun Islam dapat dicontohi oleh generasi muslim pada hari ini. Telah menjadi tradisi dunia Islam dahulu untuk mendedahkan terlebih dahulu kepada generasi pelajar mengenai ilmu-ilmu yang menjadi fardhu ain seperti aqidah, fiqh, akhlak dan tajwid. Kemudian mereka didedahkan dengan ilmu-ilmu fardhu kifayah seperti perubatan, pertukangan, kejuruteraan, sains dan sebagainya. Akhirnya, dunia Islam dahulu menjadi maju dan menguasai dunia ini dalam segala aspek. Lahirlah tokoh-tokoh ilmuan ulung Islam yang terkenal dalam pelbagai bidang seperti Abu Musa Jabir Ibn Hayyam (721-815) - 
pengasas makmal kimia dan menemui asid nitrik, Muhammad Ibn Musa al-Khawarizmi (780-850) - meneroka ilmu optik dan fizik, Abu Bakar Muhammad Ibn Zakariyya alRazi (865-925)- menghasilkan ensiklo-pedia perubatan dan membuat pengkelasan sebatian kimia, Ibnu Haytham (965-1041) menemui teori pembiasan cahaya, AlBayruni (973-1050) - menggariskan prinsipprinsip astronomi, Ibnu Sina (980-1037) menghasilkan ensiklopaedia falsafah dan menghasilkan buku-buku tentang perubatan, dan Ibnu Batuta (1304-1378) - menerokai ilmu pelayaran dan membuat catatan tentang pelayarannya (lihat Mohd Yusof Othman, 2012). Islam telah menyediakan ramuan yang terhebat. Sarjana silam telah menggunakan ramuan tersebut sehingga mereka berjaya menguasai ilmu ukhrawi dan duniawi. Ramuan ini terhasil adalah menerusi pendekatan bersepadu.

\section{KESIMPULAN}

Dalam menghadapi cabaran era revolusi industri 4.0 ini serta isu-isu yang dibangkitkan dalam masyarakat, pendidikan Islam perlu merentasi kurukulum manakala pendekatan bersepadu perlu dilaksanakan sebaiknya dalam proses pendidikan negara. Pendekatan bersepadu perlu dimantapkan semula dan dipraktikkan ke arah mencipta golongan ulama, cendekiawan, sarjana, pemikir dan pemimpin. Kombinasi antara ilmu fardhu ain dan fardhu kifayah, tradisional dan kontemporari, serta ilmu naqli dan ilmu aqli, boleh melahirkan insan terdidik yang bijak memanfaatkan ilmu dan teknologi ke arah menjayakan misi kehidupannya iaitu sebagai hamba Allah s.w.t. dan khalifahNya di atas muka bumi, yang mampu memakmurkan masyarakat serta membawa mereka ke arah kejayaan di dunia dan akhirat. Pendekatan bersepadu merupakan perisai yang berkesan bagi masyarakat menangani gejala-gejala negatif hasil daripada kemajuan teknologi pada hari ini. Teknologi tidak buruk tetapi yang memburukkan keadaan ialah manusia yang menggunakan teknologi itu. Pendekatan bersepadu akan mendidik masyarakat bagaimana mengguna, menyaring dan memanfaatkan teknologi. Pendekatan bersepadu perlu diamalkan dalam penggubalan sukatan pelajaran, pelaksanaan metod penyampaian dan pentaksiran, sebarang aktiviti dalam pembinaan pelajar termasuk pengembangan bakat para pendidik.

\section{RUJUKAN}

Al-Quran al-Karim.

Abdul Halim Muhamad. 1985. Asas Pemikiran Sebagai Ulasan kepada Kertas Prosiding Tentang Forum Pendidikan Sepadu pada 30 Oktober 1984. Kertas kerja Bengkel Pendidikan 
Sepadu. Bangi: Universiti Kebangsaan Malaysia.

Alvin Toffler. 1970. Future Shock. New York: Random House.

Al-Fakhru al-Razi t. th. Al-Tafsir al-Kabir. Jilid ke-3. Beirut: Dar Ihya' al-Turath al- ${ }^{\mathrm{c}}$ Arabi.

Ibn Kathir, Abu al-Fida' Isma'il. t. th. Tafsir Ibn Kathir. Jilid ke-2. Kaherah: Dar alMannar.

Ibn Khaldun, Abu Zayd 'Abd al-Rahman bin Muhammad bin Khaldun. 1990. Muqaddimah. Beirut: Dar Ihya alTurath.

Joy A. Palmer Cooper (Ed.) 2016. The Routledge Encyclopaedia of Educational Thinkers. Routledge: New York.

Mohd Kamal Hassan. 1984. Penghayatan Islam dalam Mempelajari dan Mengembangkan Ilmu. Kertas kerja Forum Pendidikan Sepadu. Bangi: Universiti Kebangsaan Malaysia.

Mohd Yusof Othman. 2012. Gagasan 1Malaysia: Kreativiti \& Inovasi dalam Pembinaan Peradaban. Putrajaya: Akademi Kenegaraan BTN.
Noresah Bt. Baharom et.al. (2007). Kamus Dewan. Edisi Ke-4, Kuala Lumpur: Dewan Bahasa \& Pustaka.

Sacid Hawwa 1989. Al-Asas fi al-Tafsir. Jilid Pertama. Kaherah: Dar al-Salam.

Syed Muhammad Naquib al-Attas. 1977. Islam: Faham Agama dan Asas Akhlak. Kuala Lumpur: Angkatan Belia Islam Malaysia (ABIM).

Tajul Ariffin Noordin \& Abdul Raof Dalip. 1986. Pendidikan Sepadu. Bangi: Universiti Kebangsaan Malaysia.

Al-Tabari, Abu Jac far Muhammad ibn Jarir 1987. Jami $^{c}$ al-Bayan fi Tafsir alQur'an. Jilid ke-2. Kaherah: Dar alRayyan Li al-Turath.

Tajul Ariffin Noordin. 2005. Pendidikan Bersepadu dalam Falsafah Pendidikan Negara. Prosiding Seminar Pendidikan 25 Tahun KUSZA. Kuala Terengganu: Kolej Ugama Sultan Zainal Abidin. 